\title{
RISK OF HEPATITIS B AND HEPATITIS C AMONG WHOLE BLOOD TRANSFUSED CHRONIC HEMODIALYSED CHRONIC KIDNEY DISEASE (CKD) PATIENTS
}

\author{
MD. ABDUL QUADER ${ }^{1}$, KHAN ANISUL ISLAM ${ }^{2}$, TASHMIM FARHANA DIPTA ${ }^{3}$, MD. ASHADUL ISLAM ${ }^{4}$
}

\begin{abstract}
:
Background: Patients with chronic renal failure on maintenance hemodialysis (MHD) have high risks of viral infections and the prevalence of transfusion transmissible viral infection is common among them. The aim of our study was to detect hepatitis $B$ and hepatitis $C$ virus in hemodialysis patients and healthy donors and to explore if there was a relationship between duration of hemodialysis and hepatitis $B$ and hepatitis $C$ in our patients.

Methodology: A cross sectional study was conducted in a private hemodialysis clinic in Dhaka city with end stage renal disease on maintenance hemodialysis and an age matched healthy donors as comparable group from July 2015 to June 2016. Serum alanine aminotransferase (ALT), serum aspartate aminotransferase (AST), HBsAg and anti HCV were determined along with duration and units of blood transfusion needed by them.

Results: Our study showed the mean age of 126 MHD patients were $42.2 \pm 11.7$ years along with 132 healthy donors as control group had mean age 39.2 \pm 9.7 years. Among the hemodialysis patients 34 (26.98\%) showed transfusion transmitted infection positivity and in control group 11 (8.33\%) showed transfusion transmitted infection positivity with the difference between two study group showed statistical significance $(p<0.001)$. History of blood transfusion showed the significant predictor of occurrence of TTV infection in hemodialysis patients $(p<0.01)$. Duration of hemodialysis and seropositivity of TTI was not significant ( $p>0.05)$. The number of units of blood transfusion and the TTI positivity also showed no significant difference ( $p>0.05)$ with $\mathrm{HBsAg}(17.46 \%)$ and anti $\mathrm{HCV}$ (9.52\%).

Conclusions: The prevalence of TTI in hemodialysis patients is significantly higher than that in healthy individuals. So, the regular screening of HBV and HCV among patients and healthy donors are strictly provided to monitor the communicable disease.
\end{abstract}

Key words: Hepatitis B, Hepatitis C, Maintenance hemodialysis, CKD patients.

Received: 12 December 2018

Accepted: 11 April 2019

DOI: https://doi.org/10.3329/bjmed.v30i2.41534

\section{Introduction:}

Chronic kidney disease (CKD) is the condition with irreversible deterioration of renal function leading to derangement and inefficiency of renal excretory and regulatory function. ${ }^{1}$ Dialysis patients have lower immune response and are at a higher risk for infections. Viral hepatitis continues to be a potential serious ailment among hemodialysis patients. Both hepatitis $B$ and hepatitis $C$ have been implicated to be the main cause of viral hepatitis among hemodialysis patients. The increased risks for hepatitis has been attributed to exposure to other viruses from other patients by the use of common equipment; and the administration of multiple blood transfusions before the availability of recombinant human erythropoietin. ${ }^{2}$
Maintenance hemodialysis (MHD) is employed for sustaining life when chronic kidney disease (CKD) patient reach end stage renal failure (ESRD). Although the benefits of this therapy are unquestioned, many complications have been associated with MHD. The dialysis setting has been recognized as a high risk environment for the transmission of blood borne infections to both patients and caregivers. There is a high risk of indirect and direct transmission of infectious agents in MHD units as vascular access is needed on a regular basis. This results in a increased potential for acquiring nosocomial infections, especially blood borne, via equipment, environmental surfaces or the hands or gloves of any personnel, which become

1. Assistant Professor, Transfusion Medicine Dept. Popular Medical College

2. Research Assistant, Transfusion Medicine Dept. BSMMU

3. Professor, Transfusion Medicine and Clinical Hematology Dept. BIRDEM

4. Chairman and Professor, Transfusion Medicine Dept. and Additional Registrar, BSMMU.

Correspondence: Dr. Md. Abdul Quader, Assistant Professor, Transfusion Medicine Dept. Popular Medical College, Email: quaderdr715@gmail.com

Bangladesh J Medicine 2019; 30 : 78-82 
contaminated by potentially infectious blood or other body fluids ${ }^{3}$.

The risk of hepatitis $B$ infection in hemodialysis patients has been reduced through the use of immunization, periodic testing, isolation of infected patients and improved disinfection procedures ${ }^{4}$. However, some hemodialysis patients develop elevated serum alanine aminotransferase levels which are usually mild and transient. The reason for this is unknown. Studies have implicated non-A and non-B hepatitis to be the current major cause of hepatitis in hemodialysis units. ${ }^{5}$ Recent studies have reported that the hepatitis $C$ virus has been identified as the major cause of non-A, non-B hepatitis ${ }^{4}$, and enzyme linked immunosorbent assays are now available to test patients and serum of blood donors.

The prevalence of transfusion transmitted virus in patients undergoing maintenance hemodialysis (MHD) units varies widely and various demographic, virologic or clinical features can explain these differences. Blood transfusion requirement and nosocomial transmission of transfusion transmitted virus within dialysis units seen to be important in the diffusion of transfusion transmitted virus in the MHD settings; however, other routes of transfusion transmitted virus acquisition may also play a role. ${ }^{6}$

This study was conducted to determine the prevalence of hepatitis $\mathrm{B}$ and hepatitis $\mathrm{C}$ virus among hemodialysis patients and compare the occurrence of hepatitis $B$ and $\mathrm{C}$ virus in healthy donors. And to explore the predictors of occurrence of infection and to determine the most frequent transfusion transmitted virus (hepatitis $\mathrm{B}$ and $\mathrm{C}$ virus).

\section{Materials and Methods:}

In this cross sectional study data from all individuals who had ESRD and underwent maintenance hemodialysis (MHD) treatment from July 2015 to June 2016 in one of the private dialysis center (Imdad-Setara Kidney Foundation) in Dhaka city, Bangladesh were analyzed. One hundred twenty six (126) patients who had been on MHD therapy for a period of more than one year and aged more than 18 years comprised the study group. One hundred thirty two (132) aged matched voluntary non remunerated blood donors who attended the center were included as controlled group. Written informed consent was obtained from both patients and blood donors (controlled group) after explaining the purpose of the study. Information was obtained by questionnaires, chart review and a personal interview. It included demographic characteristics, the number of years on hemodialysis, the history and number of blood unit transfused.

Hemodialysis procedure: The patients received routine hemodialysis with four hour treatments performed once to thrice weekly. A hollow-fiber type of dialyzer was used with standard acetate or bicarbonate solutions. Dialyzers were reused in all patients. The individual dialyzers were cleaned and rinsed by sterile normal saline solution and disinfected with formaldehyde. Prior to the next hemodialysis, the dialyzer were flushed with $2,500 \mathrm{ml}$ of normal saline solution. The dialysis machines were disinfected with chloroform, acetic acid, or citric acid, depending upon the dialysis solution.

Serologic testing: The following biochemical assays were performed: serum alanine aminotransferase (ALT), serum aspartate aminotransferase (AST), hepatitis B surface antigen (HBsAg), and antibody to hepatitis C. serum ALT and AST were analyzed by (Cobas 2000 analyzer). Hepatitis B marker was tested by enzyme immunoassay (Excel, Biotest and Biotech co. USA). Anti$\mathrm{HCV}$ was measured by enzyme-linked immunosorbent assay (Excel, Biotest and Biotech co. USA).

Data analysis: Data analysis was done by determining frequencies and percentages for the variables under study. To determine the possible relationship between the number of blood transfusions and hepatitis B and $\mathrm{C}$, as well the duration of hemodialysis and hepatitis $\mathrm{B}$ and $\mathrm{C}$, Chi-square test for trends was utilized with $\mathrm{p}<0.05$ as significant.

\section{Results:}

Of the 126 MHD patients, 80 (63.49\%) were males and $46(36.51 \%)$ were females. Their mean age was $42.21 \pm 11.7$ years. Among the control groups there were 94 (71.21\%) males and 38 (28.79\%) were females with mean age of39.2 \pm 9.7 years [Table-I]. Thirty four (26.98\%) patients and eleven (8.33\%) control groups subject showed TTV positivity. The remaining of both groups showed TTV negativity and the difference between the two group was statistically significant $(p<0.001)$ [TableII]. History of blood transfusion is the only significant predictor of occurrence of TTV infection in MHD patients $(\mathrm{p}<0.01)$, while age, duration of hemodialysis, HBsAg and HCV infection, elevated ALT and AST levels were not significant predictor for TTV infection [Table-III]. The patients were divided into 4 groups according to the duration of hemodialysis as $<1$ year; 1-2 year; 2-3 year and $>3$ years. Eight patients had been on hemodialysis for $<1$ year, 11 patients between 1 to 2 years, 7 patients between 2 to 3 years and 8 patients $>3$ year who showed TTV positivity. The overall test for significance between duration of hemodialysis and TTV positivity was not significant $(p>0.05)$ by Chi-square. TTV negativity showed by 31 patients who had been on hemodialysis for $<1$ year, 26 patients between 1-2 years, 21 patients between $2-3$ years and 14 patients $>3$ years [Table-IV]. Regarding number of blood transfusion and TTV infection patients were divided into four groups. Among the 34 TTV positive patients, 5 patients had $<5$ units of blood transfusion. Twelve patients had 6-10 units, 9 patients had 11-15 units and 8 patients had $>20$ units of blood transfusion. The overall test for significance between number of blood transfusion and TTV positivity was not significant $(\mathrm{p}>0.05)$. Of the 92 TTV negative patients 29 had $<5$ units of blood transfusion; 25 patients between 6-10 units; 22 patients $11-15$ units and 16 patients had $>20$ units of blood [Table-V]. 
Table-I

Distribution of age and sex of case and control group.

\begin{tabular}{llccc}
\hline & & Group I (case) $\mathrm{n}=126$ & Group II (control) $\mathrm{n}=132$ & $\mathrm{p}$-value \\
\hline Age (Year) & & $42.2 \pm 11.7$ & $39.2 \pm 9.7$ & $>0.05$ \\
Sex & Male & $80(63.49 \%)$ & $94(71.21 \%)$ & $38(28.79 \%)$ \\
& Female & $46(36.51 \%)$ & $132(100.00 \%)$ & \\
\hline Total & $126(100.00 \%)$ & & \\
\hline
\end{tabular}

$\mathrm{X}^{2}=1.75 \quad \mathrm{p}>0.05$

Table-II

Distribution of cases and controls according to prevalence of TTV infection.

\begin{tabular}{lccc}
\hline & Group I (case) $n=126$ & Group II (control) $n=132$ & p-value \\
\hline TTV positive & $34(26.98 \%)$ & $11(8.33 \%)$ & $<0.001$ \\
TTV negative & $92(73.02 \%)$ & $121(91.67 \%)$ & \\
\hline Total & $126(100.00 \%)$ & $132(100.00 \%)$ & \\
\hline
\end{tabular}

$\mathrm{X}^{2}=15.56 \quad \mathrm{P}<0.001$

Table-III

Showing regression analysis for prediction of occurrence of TTV infection.

\begin{tabular}{lcccc}
\hline & B & \multicolumn{2}{c}{$95 \%$ for $\beta$} & P value \\
\cline { 3 - 4 } & & Lower & Upper & $>0.05$ \\
Age & 1.05 & 0.99 & 1.2 & $<0.05$ \\
H/O blood transfusion & 14.72 & 2.65 & 80.33 & $>0.05$ \\
Duration of hemodialysis & 0.98 & 0.93 & 1.04 & $>0.05$ \\
HBsAg & 0.43 & 0.08 & 2.57 & $>0.05$ \\
HCV & 0.20 & 0.04 & 1.24 & $>0.05$ \\
ALT & 1.02 & 0.97 & 1.08 & $>0.05$ \\
AST & 1.03 & 0.98 & 1.08 & \\
\hline
\end{tabular}

Table-IV

Distribution by duration of hemodialysis and hepatitis.

\begin{tabular}{|c|c|c|c|c|c|c|}
\hline \multirow[t]{3}{*}{ Duration of hemodialysis } & \multicolumn{4}{|c|}{ TTV positive } & \multicolumn{2}{|c|}{ TTV negative } \\
\hline & \multicolumn{2}{|c|}{ HBsAg } & \multicolumn{2}{|c|}{$\mathrm{HCV}$} & \multirow[b]{2}{*}{$\mathrm{n}$} & \multirow[b]{2}{*}{$\%$} \\
\hline & $\mathrm{n}$ & $\%$ & $\mathrm{~N}$ & $\%$ & & \\
\hline$<1$ year & 5 & 3.97 & 3 & 2.38 & 31 & 24.60 \\
\hline 1-2 year & 7 & 5.55 & 4 & 3.17 & 26 & 20.63 \\
\hline 2-3 year & 5 & 3.97 & 2 & 1.59 & 21 & 16.67 \\
\hline >3 year & 5 & 3.97 & 3 & 2.38 & 14 & 11.11 \\
\hline Total & 22 & 17.46 & 12 & 9.52 & 92 & 73.02 \\
\hline
\end{tabular}

$\mathrm{X}^{2}=2.954 \quad \mathrm{p}>0.05$

Table-V

Distribution by number of blood transfusion in hemodialysis patient and hepatitis.

\begin{tabular}{|c|c|c|c|c|c|c|}
\hline \multirow{3}{*}{$\begin{array}{l}\text { Blood Transfusion } \\
\text { Number of units }\end{array}$} & \multicolumn{4}{|c|}{ TTV positive } & \multicolumn{2}{|c|}{ TTV negative } \\
\hline & \multicolumn{2}{|c|}{ HBsAg } & \multicolumn{2}{|c|}{$\mathrm{HCV}$} & & \\
\hline & $\mathrm{n}$ & $\%$ & $\mathrm{~N}$ & $\%$ & $\mathrm{n}$ & $\%$ \\
\hline$<5$ unit & 3 & 2.38 & 2 & 1.59 & 29 & 23.02 \\
\hline 6-10 unit & 8 & 6.35 & 4 & 3.17 & 25 & 19.84 \\
\hline 11-15 unit & 6 & 4.76 & 3 & 2.38 & 22 & 17.56 \\
\hline$>16$ unit & 5 & 3.97 & 3 & 2.38 & 16 & 12.70 \\
\hline Total & 22 & 17.46 & 12 & 9.52 & 92 & 73.02 \\
\hline
\end{tabular}

$\mathrm{X}^{2}=1.815 \quad \mathrm{p}>0.05$ 


\section{Discussion:}

In patients on maintenance hemodialysis (MHD), the risk of hepatitis is still a serious problem despite the availability of serological tests and vaccines for hepatitis $B$ virus infection and universal precaution standards and infection control measures. Available data suggest that $\mathrm{HCV}$ has become the most common cause of acute hepatitis in dialysis patients following the implementation of infection measures for HVB. ${ }^{7}$ Patients on hemodialysis are considered to be at risk of infection by various bloodborne viruses, including TTV. The frequency of TTV infection among patients on MHD varies widely. The geographical distribution, the methods used for TTV DNA testing, the size of the study group and the presence of various demographic, virological or clinical features of dialysis patients contribute to the difference. ${ }^{8}$

The aim of our study was to determine TTV infection (hepatitis B C virus) among MHD patients and comparing them with healthy donors and to study the predictors of occurrence of infection. The prevalence of TTV among MHD patients ranged from $2.5 \%$ to $64.8 \%$ in various studies. Halfon et $\mathrm{al}^{9}$ in France found $2.5 \%$, in the study by Forns et $\mathrm{al}^{10}$ in Spain found $53 \%$, in Japan Oguchi ${ }^{11}$ and Utsonomy ${ }^{12}$ found 30\% and $64.8 \%$ respectively. $9.3 \%$ in the study by Kheradpezhouh et $\mathrm{al}^{13}$ in Tabriz, northern Iran, $64.8 \%$ in the study by Abou-Donia et $\mathrm{al}^{14}$ in Egypt and $16.7 \%$ in the study by Ataei et $\mathrm{al}^{15}$ in Iran found TTV. In our study, the prevalence of TTV in MHD patients was statistically significantly higher $(26.98 \%)$ compared with $8.33 \%$ that in the control group $(\mathrm{p}<0.001)$. The present study showed similar result with Chan et $\mathrm{al}^{16}$, who found that TTV was $61 \%$ in HD patients compared with $15.6 \%$ in healthy donors. The present study also agreed with study done by Martinez et $\mathrm{al}^{17}$ revealed statistical significance of TTV in HD patients $(16 \%)$ than that among the healthy population $(2 \%)(p<0.001)$ and Revonera et $\mathrm{al}^{18}$ who reported TTV-DNA in dialysis patients $(41.7 \%)$ was significantly higher than that in the healthy population $(10.7 \%)(\mathrm{p}<0.001)$.

The prevalence of HBsAg and anti-HCV was determined in 126 MHD patients and 132 voluntary donors. Patients on chronic hemodialysis have been known to be at high risk for HBV infection, yet there is a scarcity of data regarding the prevalence of HBV markers in these patients. Our results show that the prevalence of HBsAg was $17.46 \%$. A few reports showed that the HBV infection marker seropositivity rate 20 to $67 \%$. Daguirdas ${ }^{19}$ reported the prevalence of HBsAg among hemodialysis patients was $1 \%$, while the incidence of HBsAg in Japan was $1.6 \%$ shown by Hayashi ${ }^{20}$. These results were much lower than our study result. But similar results found with Kheradpezouh et $\mathrm{al}^{13}(9.3 \%)$ and Ataei et $\mathrm{al}^{15}$ (16.7\%) study.

The prevalence of anti-HCV varies widely from $1 \%$ to $32 \% 5,7,20,21$. The highest reported incidence from a single hemodialysis unit was observed by Schlipkoter et $\mathrm{al}^{22} 37 \%$. The reason for this variation in prevalence rates of anti-HCV among hemodialysis patients reported from different studies of the world is unknown.
Others have attributed this to the incidence of $\mathrm{HCV}$ infection in the general population, the infection control measure used by a particular dialysis unit, or the profile of the HD patient population. The prevalence of anti-HCV in our study is low $(9.52 \%)$. Study done by Oguchi et $\mathrm{al}^{20}$ found the prevalence of anti-HCV was $17 \%$ and Jeffers LS $^{21}$ et al showed prevalence of antiHCV 19.1\% which were much higher than our study.

The prevalence of TTV in healthy donors ranged from $1 \%$ to $40 \%$ in Matsubara $\mathrm{H}$ et $\mathrm{al}^{23}$ study. As more inclusive primer was used to detect the different genotypes, the reported prevalence among blood donors increased dramatically, approaching $100 \%$ in some studies $^{24}$. Vasilyev et $\mathrm{al}^{25}$ reported that the prevalence of TTV in the healthy blood donors was $94 \%$. However, the present study showed the prevalence of TTV in healthy blood donors was $8.33 \%$. The present study result differ with the previous study results ${ }^{23,24,25}$.

In our study, the relationship between positivity of $\mathrm{HBsAg}$ and number of blood transfusion were not statistically significant. The prevalence of anti-HCV in our study is low $(9.52 \%)$; however, its association with duration of hemodialysis treatment and the number of blood transfusion is not statistically significant. Many reports indicate that the prevalence of anti-HCV correlates with the duration of hemodialysis and/or the amount of blood transfusion ${ }^{20,26}$. An increased incidence of anti-HCV $(36 \%)$ in patients with longer time in hemodialysis has been reported by Hardy and collegues ${ }^{4}$. They also noted that the large number of units of blood transfusion was also related to the HCV exposure. Our study also demonstrated that the prevalence of anti-HCV may be associated with longer maintenance hemodialysis.

Study done by Oguchi $\mathrm{H}$ et $\mathrm{al}^{20}$ showed that their patients had significantly longer duration of hemodialysis and more blood transfusion. In addition, they noted that the number of transfusion was received also related to the duration of hemodialysis. The fact that anti-HCV positivity was directly proportional to the number of blood transfusion is very high ${ }^{27}$.

Our study provided evidence that age of patients, duration of hemodialysis, HBsAg and HCV infection and ALT and AST levels were not significant predictors of TTV positivity in hemodialysis patients. This result coincides with that reported by many studies ${ }^{14,8,17,28,29}$. In contrast to our study, Itoh et $\mathrm{al}^{30}$ reported a higher prevalence of TTV in blood donors with elevated ALT levels $(32 \%)$ than in those with normal levels $(16 \%)$. Further studies regarding the clinical and epidemiological significance of coexistence anti-HCV and liver function is warranted.

\section{Conclusion:}

The results of our study show the need for regular screening of $\mathrm{HBV}$ and $\mathrm{HCV}$ among patients and donors of hemodialysis unit, the strict observation of communicable disease precautions by thorough donors and patient education and monitoring. It seems necessary to take serious measures to reduce the risk of TTV transmission to hemodialysis patients.

Conflict of Interest: Nil. 


\section{References:}

1. Soriano Cabrera S. Definition, classification of stages, and prevalence of chronic kidney disease. Guidelines for early detection. Risk factors for chronic kidney disease. Nefrologia 2004; 24 suppl(6): 27-34,187-235.

2. Ma Nanette V, Bernal-Sunding, Rose Marie Ho-Yu, Gerardo F Ibarra. The Prevalence of hepatitis B and C among chronic hemodialysis patients and hemodialysis staff members at UERMMMC. Phil J Microbiol Infect Dis 1995; 24(2):54-58.

3. Zuckerman M. Surveillance and control of blood borne virus infections in haemodialysis units. J Hosp Infecct 2002; 50:1-5.https://doi.org/10.1053/jhin.2001. 1068.PMid:11825044

4. Hardy NM, Sandroni S, Danielson S, Wilson WJ. Antibody to hepatitis $\mathrm{C}$ virus increases with time on hemodialysis. Clin Nephrol 1992; 38(1):4448..PMid:1499168 5. Zeldis JB, Depner TA, Kuramoto IK, Gish RG, Holland PV. The prevalence of hepatitis $\mathrm{C}$ virus antibodies among hemodialysis patients. Ann Intern Med 1990; 112(12):958-960. https://doi.org/10.7326/0003-4819-112-12958.PMid: 2111110

6. Fabrizi F, Martin P, Lunghi G, Locatelli F. TT virus infection in end-stage renal disease (ESRD). J Nephrol 2001; 14:80-87..PMid:11411018

7. Niu MT, Coleman PJ, Alter MJ. Multicenter study of hepatitis $\mathrm{C}$ virus infection in chronic hemodialysis patients and hemodialysis staff members. Am J Kidney Dis 1993; 22(4):568-573. https://doi.org/10.1016/ S0272-6386(12)80930-9

8. Hsu BG, Lo SY, Wang LY et al. TT virus infection in patients on maintenance hemodialysis in eastern Taiwan. Acta Nephrologica 2004; 18(2):71-74.

9. Halfon P, Bouriere M, Feryn JM et al. Prevalence of transfusion transmitted virus (TTV) in population at different risk for hepatitis virus: hemodialysis, chronic hepatitis C and cryptogenic hepatitis patients. J Hepatol 1999 Mar; 30(3):552-56.https://doi.org/10.1016/ S0168-8278(99)80120-2

10. Forns X, Hegerich P, Darnell A, Emerson SU, Purcell $\mathrm{RH}$, Bukh J. High prevalence of TTvirus (TTV) infection in patients on maintenance hemodialysis: frequent mixed infections with different genotypes and lack of evidence of associated liver disease. J Med Virol 1999; 59:313-317. https:// doi.org/10.1002/(SICI) 10969071(199911)59:3<313::AID-JMV9>3.0.CO;2-B

11. Oguchi T, Tanaka E, Orii K, Kobayashi M, Hora K, Kiyosawa K. Transmission of and liver injury by TT virus in patients on maintenance hemodialysis. J Gastrolenterol 1999; 34(2):234-40.https://doi.org/ $10.1007 / \mathrm{s} 005350050249$

12. Utsonomiya S, Yoshioka K, Wakita T et al. TT virus infection in hemodialysis patients. Am J Gastroenterol 1999; 94(12):3567-70.https://doi.org/10.1111/ j.1572-0241. 1999.01647.x PMid:10606320

13. Kheradpezhouh M, Taremi M, Gachkar L, Aghabozorgi $\mathrm{S}$, Khoshbaten M. Presence and significance of transfusion-transmitted virus infection in Iranian patients on maintenance hemodialysis. J Microbiol Immunol Infect 2007; 40:106-111.PMid:17446957

14. Abou-Donia H, Selim H, El-Koraei A, Ghazal A, Kabbary N. TT virus DNA among hemodialysis patients in Alexandria. Egypt J Med Microbiol 2007; 16(1):8-11.
15. Ataei B, Naeini AE, Khorvash F, Yazdani MR, Javadi AA. Prevalence of transfusion transmitted virus infection in hemodialysis patients and injection drug users compared to healthy blood donors in Isfahan, Iran. Gastroenterol Res Pract 2012; 67:19-27.https:// doi.org/10.1155/2012/671927

16. Chan YJ, Hsu YH, Chen MC et al. TT virus infection among hemodialysis patients at a medical center in Taiwan. J Microbiol Immunol Infect 2000; 33:1418.PMid: 10806958

17. Martinez NM, Garcia F, Garcia-Valdecasas et al. Prevalence and viral persistence of TT virus on hemodialysis. Eur J Clin Microbiol Infect Dis 2000; 19:878-80. https:/ / doi.org/ 10.1007/s100960000382. PMid:11152315

18. Rivanera D, Lozzi MA, Idili C, Lilli D. Prevalence of TT virus infection in Italian dialysis patients. Pathol Biol (Paris) 2009; 57(1):97-100.https://doi.org/10.1016/ j.patbio.2008.07.014 PMid:18842354

19. Daguirdas JT, Ing TS. Handbook of Dialysis. 2nd edi. Philadelphia: JB Lippincott; 1994.

20. Oguchi H, Miyasaka M, Tojunaga S et al. Hepatitis virus infection (HBV and HCV) in eleven Japanese hemodialysis units. Clin Nephrol 1992; 38(1):3643.PMid:1499167

21. Jeffers LJ, Perez GO, de Madina MD. Hepatitis C infection in two urban hemodialysis units. Kidney Int 1990; 38:320-322.https://doi.org/10.1038/ki.1990. 203.PMid:2119469

22. Schilpkoter U, Roggendorf M, Ernst G. Hepatitis C virus antibodies in hemodialysis patients. Lancet June 1990; 335(8702): 1409-1410.https://doi.org/10.1016/01406736(90)91296-M

23. Matsubara H, Michitaka K, Horiike N et al. Existence of TT virus DNA in extracellular body fluids from normal healthy Japanese subjects. Inter virology 2000; 43:1619. https://doi.org/10.1159/000025018

24. Hsu HY, Ni YH, Chen HL, Kao JH, Chang MH. TT virus infection in healthy children, children after blood transfusion, and children with non-A to E hepatitis or other liver diseases in Taiwan. J Med Virol 2003; 69(1):6671.https://doi.org/10.1002/jmv.10249.PMid:12436479

25. Vasilyev EV, Trofimov DY, Tonevitsky AG, Ilinsky VV, Korostin DO, Rebrikov DV. Torque teno virus (TTV) distribution in healthy Russian population. Virol J 2009; 6:134. https://doi.org/10.1186/1743-422X-6134.PMid:19735552 PMCid:PMC2745379

26. Hayashi, Nakashima K, Kajiyanna W et al. Prevalence of antibody to hepatitis $\mathrm{C}$ virus in hemodialysis patients. Am J Epidemiol 1991; 134(6):651-657. https:/ / doi.org/ 10.1093/oxfordjournals.aje.a1 16137.PMid:1659184

27. Dentico P, Buogiorno R, Volpe A et al. Prevalence and incidence of hepatitis $\mathrm{C}(\mathrm{HCV})$ in hemodialysis patients: study of risk factors. Clin nephrol 1992 Jul; 38(1):4952.PMid:1499169

28. Campo N, Brizzolara R, Sinelli N et al. TT virus infection in hemodialysis patients. Nephrol Dial Transplant 2000; 15:1823-26.https://doi.org/10.1093/ndt/ 15.11.1823.PMid:11071972

29. Irshad M, Mandal K, Singh S, Agarwal SK. Torque teno virus infection in hemodialysis patients in North India. Int Urol Nephrol 2010; 42:1077-83.https://doi.org/ 10.1007/s11255-009-9648-4.PMid:19777363

30. Itoh $\mathrm{K}$, Takahashi M, Ukita M, Nishizawa T, Okamoto $\mathrm{H}$. Influence of primers on the detection of TT virus DNA by polymerase chain reaction. J Infect Dis 1999;180:1750-51. https://doi.org/10.1086/ 315107.PMid:10515849. 